\title{
Technology and Toil in Nineteenth-Century Scotland: An Overview
}

\section{Bill Knox}

\section{(2) OpenEdition \\ 1 Journals}

\section{Electronic version}

URL: https://journals.openedition.org/etudesecossaises/191

DOI: 10.4000/etudesecossaises. 191

ISSN: 1969-6337

\section{Publisher}

UGA Éditions/Université Grenoble Alpes

\section{Printed version}

Date of publication: 30 April 2009

Number of pages: 65-77

ISBN: 978-2-84310-138-0

ISSN: 1240-1439

\section{Electronic reference}

Bill Knox, "Technology and Toil in Nineteenth-Century Scotland: An Overview", Études écossaises

[Online], 12 | 2009, Online since 30 April 2010, connection on 11 April 2023. URL: http://

journals.openedition.org/etudesecossaises/191 ; DOI: https://doi.org/10.4000/etudesecossaises.191

All rights reserved 


\section{Technology and Toil in Nineteenth-Century Scotland: an overview}

Creativity is an essential aspect of what it means to be human. We can choose to express this creativity in works of the imagination, such as writing poetry, composing music or painting pictures, but we can also express ourselves in other forms of activity which are perhaps less esoteric, however still imaginative, such as building bridges, making furniture, constructing railway engines, landscaping gardens, and so on. Work then is essential to human existence; it provides outlets for our creativity; it provides a basis on which to build social relationships with other people; and collectively it develops the material basis for a civilised society. The impulse towards creativity exists in us all; however, in a capitalist society the mental and physical energies used in the creative process have been transformed into a commodity subject to the laws of supply and demand. Work in this context is based less on voluntary impulse and more on involuntary compulsion. The majority of us simply must work to live. Human beings devoid of ownership of capital must sell their labour power to those who do. From this basic economic premise Marxists, such as the hugely influential Harry Braverman in his ground-breaking book - Labour and Monopoly Capital (1974) - have claimed that there exists a fundamental conflict in modern society between those who sell their labour and those who buy it; in other words a class struggle. In the workplace this struggle coalesced round the question of skill. Braverman argued that there was basic imperative within capitalism towards the deskilling of the working class and in his book he sketched a transition from production regimes dominated by scientific knowledge and craft skills of workers to a situation in which management exercised full control over the knowledge and design of the production process. There were three key elements in the transition from control to subordination; firstly, there was a total divorce of mental and manual labour - separation of conception from execution; secondly, and more important, the labour 
process was made completely independent of the autonomy, creativity and ability of the individual worker; and, lastly, capitalists or management functionaries assume control over every step of the labour process. Advanced capitalism thus was actively proletarianizing workers, manual and white collared, in order to cheapen the cost of production and, at the same time, weaken worker resistance to capitalist control through deskilling. However, unknowingly it was also creating its own gravediggers. The ineluctable trend towards homogeneity and degradation of labour were important agents in class formation. By eliminating the divisions between workers at the site of production and consequently in the wider society, the development of capitalist technology and modes of labour organisation and discipline associated with it was creating a working-class solidarity which would eventually lead to the overthrow of capitalism by the proletariat.

At a theoretical level Braverman was not without his critics and a number of telling questions were raised regarding his methodology and his theoretical shortcomings. Although space does not allow for a deeper analysis of Labour and Monopoly Capital, perhaps the most damning criticism is that for a Marxist he almost neglects the role of class struggle in the workplace, the role of gender in mediating that struggle, and, finally, the role of markets and products in modifying the extent to which deskilling can be carried. Some critics went as far as to argue that the nineteenthcentury workplace far from being a site of conflict was instead a terrain of compromise. Given the uneven development of industrial capitalism, the nature of work patterns remained disjointed and haphazard and far from being deskilled many workers were able to retain a large measure of control over the work process. The labour intensive methods favoured by employers, and the highly differentiated products markets they operated within, ensured that skill remained at a premium throughout the nineteenth century. Consequently, the scope employers had to deskill was limited, and because of this, they went out their way to nurture them (Joyce, 1984).

Taken as a whole this critique amounted to a complete rejection of Braverman's theory of deskilling and, as a consequence, a denial of the Marxist concept of class struggle as the determinant of power and authority in the sphere of production. By shifting the focus of the historian's concerns away from the arena of class conflict to the terrain of compromise, industrial relations could be analysed in terms of a search for a mutually reciprocal agreed set of rules and codes of conduct, rather than a struggle over the distribution of the social product. Patrick Joyce's 
notion of "reciprocity" became the key term in the new social histories of the workplace.

Thus, there exists an ongoing debate between Marxist and revisionist historians regarding these fundamental questions of class and power. But where does Scotland figure in these debates? Unfortunately, only in passing; which is rather bizarre given the rapid expansion of coal, engineering, iron and, especially shipbuilding in the second half of the nineteenth century, which resulted, in the west of Scotland, in the greatest concentration of skilled workers anywhere in the world with the possible exception of the Rhur. Glasgow became the second city of the Empire and the west of Scotland its workshop. Scotland thus is an ideal location for the study of the relationship between technological change and skill. In examining this relationship it is perhaps convenient to divide the years 1800 to 1914 into three periods; firstly, 1800-1850, which was defined by the growth the of the cotton industry; secondly, 1850-1880s, which witnessed the rise and prominence of heavy industry; and, finally, 1880s to the First World War, which some historians have described as a second industrial revolution (Mann, 1983).

The years between 1800 and 1850 witnessed a transformation in the social relationships in industry. The class structure became more clearly defined as industry grew in size and a growing chasm developed between masters and men. This was most visible in the cotton industry, but it also was seen in trades which had a pre-industrial origin. The major change taking place in the cotton industry was the mechanisation of spinning and the growth of factory production. The introduction of the steampowered spinning mule reorganised production by marginalising the role of female spinners and downgrading them to ancillary or supplementary work, such as piecing. By establishing an informal apprenticeship system the male spinners were able to control the supply of labour and to a large extent (in periods of expansion) the rate for the job. Advances in technology, therefore, increased the power of the male cotton spinner, and employers retaliated by tightening industrial discipline, such as the use of fines for breaches of managerial designed codes of working (Fraser, 1976), which led to strikes and the formation of trade unions in the 1820s. However, male dominance of the labour process in spinning was only achieved at the expense of women spinners and those males outside the kinship and friendship networks of the mule spinners.

If the tensions in the spinning mills emerged over questions of control and discipline, in the skilled trades the issues tended to be connected with specialisation. Shoemaking underwent a complete reorganisation of the division of labour with the cutting out of the leather and the sewing together of the uppers established as separate operations (Gray, 
1976). The millwright's skills were broken up into a series of sub-divided tasks requiring a separate worker to perform them; a phenomenon that led to the creation of the modern engineering industry. Planers, fitters, turners, borers, and so on, were trained to carry out a portion of the millwright's craft (Burgess, 1970). In the building industry there was also a drive towards specialisation of labour. The trade of carpenter and joiner and that of plumber / glazier / painter were broken down into constituent parts (Book of Trades, 1862). Finally, in the coal industry a massive expansion took place as a result of the boom in iron production in the 1830s and 1840s. Large integrated coal and iron consortiums such as Bairds in Lanarkshire developed as a result, forcing many previously independent coal workers into waged labour. Although the majority of employers could do little to control the labour process underground due to the dispersed nature of coal-getting, the large companies were able to introduce an early version of the longwall method of coal production (see below) which reduced dependency on skilled colliers and intensified supervision of worker performance (Campbell, 1979).

However, the intensification of the division of labour did not necessarily end on-the-job control and because of this a certain amount of autonomy continued to be enjoyed by many skilled workers. Edinburgh stonemasons let their hammers fall without striking if time was called as an assertion of their right to control their own pace of work. In the building trade, bricklayers' labourers were not allowed to use the trowel (Morris, 1983). This also applied in the coal industry, in spite of managerial attempts to tighten industrial discipline. The dispersed nature of coal-getting made supervision difficult especially in the smaller concerns and this left the colliers with a degree of responsible autonomy unknown to most industrial workers. But the changes which had taken place in Scottish industry generally ensured that no one occupation controlled the labour process in the way that, say, the shipwright in shipbuilding, or the millwright in engineering, had done. Thus employers were more able to challenge historically sanctioned wage rates and privileges and subject craftsmen to competition from 'half bred' men, as well as using downturns in the trade cycle to further this strategy.

The first half of the nineteenth century has been described as the "age of manufacture", but another way of describing might be the "age of uncertainty". These insecurities did not disappear after 1850, but in the third quarter of the nineteenth century technological change did not appear as threatening. The expansion of the economy brought with it not only more jobs and higher wages, but also new products, which called on an even greater demand for a variety of skills. However, even within this optimistic period of expansion there were industrial casualties. 
Cotton was perhaps the most affected by technological innovation with the introduction of the self-acting spinning mule, which was gradually appropriated by female spinners. Similarly, shipbuilding experienced profound redistribution of skill and heightened the division of labour with the change from wood to iron and, later, steel construction. As a result the shipwright was marginalised, but the change in material created a highly skilled class of metal workers, whose job it was to shape, bend and join hot iron plates. However the new sub-division of labour meant that no trade was capable of controlling the work process. As W. C. Steadman put it:

In the building of the hull of an iron ship, the work which in earlier times, would have been done by one man $[\ldots]$ is now divided up amongst men in several branches, such as platers, riveters, holders-up, putters-in, drillers. What have originally been branches of one trade, have now become distinct trades in themselves. (Steadman, 1895)

In other trades changes were confined to the reorganisation of production, which increased firm and product specialisation, and furthered intensified the division of labour. In engineering local specialisms began to emerge in the 1850s and 1860s. Bertrams in Edinburgh was already a noted manufacturer of paper-making machinery by the early 1850s, and engineering firms in Leith specialised in marine engineering (Gray, 1976). In the Glasgow area, locomotives, textile machines and marine engineering were specialised product lines. As the president of the Institute of Mechanical Engineers put it 1874: "within the last few years [...] the business of mechanical engineering has divided itself into distinct branches so that the locomotive builder is little more than locomotive builder". The decline of the multi-product engineering workshop reduced the need for all round skills; indeed, it was rare after 1850 for apprentices in large workshops to be trained in all aspects of the engineer's craft and they became specialised as either fitters or turners (Knox, 1980). In the coal industry most of the innovations introduced in this period were aimed at improving the transport of coal from the coal face to the pithead. Employers concentrated on reducing or restricting the autonomy of the colliers by tightening industrial discipline through the employment of more supervisory workers and introducing new contracts which made all agreements terminable on a day's notice (Campbell, 1979).

Outside of the cotton industry, the technical improvements in this period were not in the main labour-displacing. The element of 'craft mystery' was still in many trades a tangible factor giving the worker a measure of control over the planning and execution of his work, something which 
was enhanced by the noted unwillingness of Scottish employers to markedly alter the capital/labour ratio due to recurring problems in world markets. Thus the control of labour was of much more concern to employers and various novel forms of subordination were introduced; directly through the use of foremen, and indirectly through the use of internal sub-contracting and paternalism (Knox, 1999).

If the third quarter of the nineteenth century was one of consolidation and specialisation, in contrast the period 1880 to 1914 saw rapid and far-reaching technological change. These changes were triggered by rising labour costs, falling productivity, high interest rates, the increase in foreign competition and the decline in overseas demand. This placed pressure on employers to rationalise production and intensify the exploitation of labour. Economic expansion was, therefore, linked to improvements in technology and labour management, and the magnitude and profoundness these changes inspired created a fundamental rift in the social relations and structure of Scottish industry, which had important knock-on effects for the growth of trade unions and the tempo of industrial relations.

The chief characteristics of this "second industrial revolution" were: firstly, the introduction of new semi-automatic machinery in coalmining, shipbuilding and engineering; secondly, the increasing use of unskilled and semi-skilled labour in trades hitherto the preserve of skilled workers; thirdly, the adoption of a rudimentary system of standardised and interchangeable parts; fourthly, the predominance of the factory over the workshop as the primary unit of production; and, finally, the introduction of aspects of Taylorism, particularly the premium bonus system, and new specialist categories of labour concerned with the design and planning and supervision of production. These changes also impacted themselves on the social relationships of production and on the various methods of manufacturing consent in the workplace for the imperatives of capital. But it is important to note that it was not simply heavy industry that was affected by changes in this period; smaller scale trades such as granite polishing, trawling, and so on, were equally affected, although, perhaps, not as profoundly as, say, coalmining.

But how did the technical revolution impact on workers? Again the impact varied from industry to industry. Engineering was at the cutting edge of technological change. The importation of semi-automatic machine tools from America transformed the role of the turner to one of preparation. Turners found that the new capstan or turret lathe reduced their work to fixing the precise rotation of the cutting edges; thereafter, the machine was operated by semi-skilled handymen. Even the fitters, whose work of rectifying inaccurate workmanship was less affected by the 
new machinery, found themselves under pressure. Semi-skilled assemblers and erectors usurped the assembly work previously the remit of the fitters, and, as a result, there was a multiplication in the number of fitters' assistants and boys in the engineering trade (Levine, 1954). As Harry McShane, referring to his time in Weir's engineering works in Glasgow, put it: "every morning each man knew the job he was going to do during the day. The jobs were so ridiculously simple that anyone could do them" (McShane and Smith, 1978). In these circumstances apprenticeship degenerated into a form of cheap labour as the number of apprentices rose and the content of training declined. The lack of job satisfaction led to not "more than 50 to 55 per cent [of Glasgow apprentices] completing their time and obtaining first or second class lines" (Scott, 1906-1907). The complementary trade of shipbuilding had less scope for innovative methods of rationalisation. Trade fluctuations continued the emphasis on labour-intensive production methods. However, in the larger yards there was the introduction of the pneumatic rivet machines which allowed the employers to make greater use of apprentice labour. A factory inspector in Glasgow noted that: "Jobs formerly done by journeymen can now with [pneumatic] tools be undertaken by apprentices." (Levine, 1954). The change from iron to steel shipbuilding also led to a "significant decrease in the level of skill of both platers and their helpers" as the manipulation of cold steel plates proved easier than dealing with heated iron plates (McClelland and Reid, 1985).

Similar encroachments into skilled work were experienced in other trades. Coalmining was increasingly subject to mechanisation, with 22 per cent of coal in Scotland in 1913 cut by machine. In addition, the "pillar and stoop" method of coal-getting was abandoned in favour of the longwall method, which allowed for greater supervision of the work group; a change that led to the erosion of the independence of the traditional bred collier. Woodworking trades in the construction industry witnessed the extension of the use of prefabricated fitments; the mass production of manufactured earthenware sanitary products decreased the skills needed by plumbers by simplifying the task of putting the work together; and, finally, in stonework the practice of dressing the stone at the quarry, the arrival of the pneumatic chisel and other cutting devices undermined the work of the mason by no small degree (Dearle, 1908).

The reorganisation of production and the encroachments by machinery into the realm of skilled handwork can viewed as part of a general process of intensifying the exploitation of labour by capital. This was furthered by the introduction of electric light which made shift work more common; as a result, excessive overtime working became a problem for trade unions in this period. For example, workers in the employ 
of the Glasgow and Southern Western Railway worked on average in the winter months of 1890 four hours and forty-eight minutes in excess of the normal ten-hour day (Bagwell, 1985). Tighter work discipline also followed. In engineering, for instance, the lock-out of 1897 won for management not only the right to control the labour process, but also to introduce new methods of supervision and a new incentive bonus scheme. By 1914, 46 per cent of fitters and 37 per cent of turners were on piece-rate payments, compared to only 5 per cent of all engineering workers in 1886 (Hobsbawm, 1964). Added to this was introduction of the premium bonus system, which involved the measuring and recording of job times by stopwatch. W. F. Watson, in his autobiography, highlighted the degrading aspects of such a system for time-served men, when he recalled that:

The plant started up before time, and one had to get down to the job immediately the hooter ceased; feed and speed bosses were employed to see that this was done. Fixed to each machine was a chart indicating the speeds to be employed, and the feed and speed men, armed with feedmeters, perambulated the shop to ensure both men and machine were working to their utmost capacity. We were not allowed to grind our own tools [...] When starting a man was given six standardized tools, ground to theoretic angles on special machines, which were changed for new ones when worn. Notices were posted forbidding any man to leave his machine or vice - labourers were to be sent to the stores for tools and tackle. We were not supposed to leave the job under any pretext - even the toilets were without doors for easy inspection. (Watson, 1935)

Although the picture so far is one of increasingly real subordination of labour to capital, as Bryn Jones points out, "management cannot construct de novo, the conditions under which labour is to function", as there is always a bargained context, which is fluid and dependent on the balance of power in the workplace (Jones, 1982). Additionally, the ability of management to control the labour process was constrained by the highly differentiated product market for Scottish/British goods. This made it difficult for employers to implement techniques of mass production: ships, machines, railway engines, boilers, and so on, all had to be constructed according to the needs of the purchaser. In the consumerorientated trades, such as the building industry and jobbing printing, the one-off nature of much of the work also imposed limitations on the use of labour-saving technology and, as a result, workers retained a measure of craft control. 
The subordination of labour to capital was, thus, never complete. Foucault's Panopticon was never realised. The incompleteness of subordination and the continued control exercised by many workers over some aspects of their working lives has, however, led some social historians to dismiss the impact of these changes on workers' (particularly skilled workers) consciousness, as well as to play down the level of conflict emanating from them. As Patrick Joyce puts it:

Employers were motivated neither by a desire to deskill or subordinate the worker, nor to introduce the most advanced technologies [...] the nature of labour and product markets, the operation of inter-capitalist competition, and the resulting reliance of workers, together always with the very important matter of cultural representations capital and labour had of themselves, and each other, often led to the adoption of a modus vivendi between the two sides, to areas of compromise and co-operation in which capital ceded to labour the "control". (Joyce, 1984)

Although industry cannot be depicted as a system of social relations based on permanent internecine struggle, and although compromise as much as conflict was written into the relationship between capital and labour, the period 1880 to 1914 stands out because of the scale and velocity of change, which "moved the question of intensified work to a general level of experience" (Price, 1984). The threats implicit in the restructuring of workplace technology and social relations to the status of the skilled worker were acute since any downgrading not only affected his income, but also his standing in the community. As Alain Touraine et al., have argued:

Protection of occupational autonomy is a defence both of occupational culture and of a communal way of experiencing work. Workers [...] [oppose] output norms not only to avoid excessive speeds of work, but also because pace destroys pride of craftsmanship in a "good job". (Touraine et al., 1965)

The trend towards specialisation of skill and the increasingly regimented work experience was lamented by craftsmen writers such as W. F. Watson, exactly because it struck at notions of craft pride, and held out the unenviable prospect of an end to traditional artisanal culture. It was this as much as anything that did much to stimulate the remarkable level of industrial conflict in this period (Kenefick and McIvor, 1996).

Work in the course of the nineteenth and early twentieth century underwent significant changes in Scotland. The all round skills of the 
pre-industrial craftsman were destroyed or recomposed in a new division of labour. The shipwright gave way to boilermakers, platers and riveters, and a host of lesser trades; in engineering the millwright's skill was broken into a series of new skills, mainly fitting and turning; in coalmining the independent collier was gradually superseded by a host of unskilled machine labourers in what was a new division of labour based on the longwall method of coal-getting. There were also as we have seen profound changes taking place in lesser trades, such as printing and plumbing. Added to this were the important changes in industrial discipline which made work increasingly dissatisfying to the skilled male worker. Did all this mean that the working class had become deskilled?

The answer depends on how one might define skilled. Specialisation meant that there was less to learn and the length of the apprenticeship was reduced accordingly from seven years to four or five. The tasks performed by the skilled man were also becoming more routine and predictable and therefore the innovative and imaginative approach to onsite problems was less a necessary attribute of the time-served man. Dissatisfaction with working conditions and new payments schemes was evident among skilled workers across the board. But it must be remembered that notions of skill are nostalgic; each generation is seen to be less skilled that the previous. Moreover, although some skills disappeared in the course of the nineteenth century, for example, handloom weaving, other skills were created by changing technologies. The introduction of electric light into the coalmines created a new class of highly skilled maintenance men. In engineering, although the new machinery eroded the skills of fitters and turners to that of mainly preparation, the expensiveness of the new machines meant that training was still necessary, since unskilled labour could easily ruin work and the machine. As M. L. Yates explained:

The complexity of modern industry, increased production speeds and improved organisation, mean that the worker is kept closely to his tasks. These still require in many cases for their satisfactory completion close concentration on the part of the intelligent man who has spent years acquiring the necessary skill. (Yates, 1937)

There was clearly then no linear trend to deskilling as argued by Braverman, rather each industry, each trade, has its own narrative of change and diversity.

Revisionist historians such as Patrick Joyce and Alistair Reid would argue that these stories confirm their view that skill was preserved and nurtured within the changing economic and technological regimes of nineteenth and twentieth century capitalism. They also confirm the 
divorce between workplace and the world of politics. For if the history of workplace relations is the story of the acceptance of the workers of the rights of private property and the unsocial ownership of wealth, then how far did the legitimisation of property also signify acceptance of the major institutions of liberal capitalism? If the answer is one of affirmation then the political story of the working class can, therefore, be written as voluntary incorporation rather than as class struggle. The problem is that it is empirically impossible to verify the relationship between the two worlds, although in saying that it might be possible to establish a number of indirect and broad connections.

In spite of the general reduction in working hours that took place in the nineteenth and early twentieth century, people still spent a considerable part of their daily lives in the workplace. Average hours for a skilled man were about fifty-four a week in 1900, but with overtime it might be much longer. Railway engine drivers and guards spent around seventy hours a week at work. The inner life of the workplace and the relationships built around it deeply embedded themselves in the consciousness of the worker. Moreover, since it was work and the status it conferred on a worker which provided him or her and family with a place in the wider society of working-class communities, the importance was multiplied in complex ways. The removal of the foundation of that status and the income that underpinned it was enough to drive displaced workers to seek a modicum of protection from the state. Thus, the pursuit of economic and social security involved them in political struggles. Furthermore, as changing work regimes impact themselves on wages and status, workers are normally moved in the direction of trade unionism. Although greater union densities do not make industrial conflict any more likely, during periods when production systems are changing and profoundly threatening inherited skills the conflicts that erupt are on such a large-scale they assume a highly symbolic nature. This is because they are not confined to simply to the specific work group or groups involved in the dispute, but engulf whole communities. Alan McKinlay's work on inter-war shipyard riveters has shown how important kinship networks were, not only in terms of recruitment to the trade, but also in enforcing solidarity during periods of industrial struggle (McKinlay, 1989). In major industrial set pieces, such as the engineers' lock out of 1897, this may have also involved the worker community in an encounter with the state in the presence of the police; normally seen by workers as proemployer. Dealing with the sharp end of the state's coercive arm inevitably produced a politicising impact on the local community. 
Thus, the workplace cannot be written off as having no relationship with the world of politics. As industrial relations became increasingly politicised by the state from the late nineteenth century onwards workers in struggle were drawn into politics whether they liked it or not. Central to this process of politicisation were the changing technological regimes in industry which threatened the livelihoods and status of skilled workers and drove them to seek the protection offered by collective solidarities. From here emerged the Labour Party and engagement with independent parliamentary activity.

\section{Bibliography}

BAGwell Phillip S., "The New Unionism in Britain: the railway industry", in W. J. Mommsen and H. G. Husang (eds), The Development of Trade Unionism in Great Britain and Germany, London, Allen and Unwin, 1985, p. 185-200.

Book of Trades, 1862.

Braverman Harry, Labour and Monopoly Capital, New York, Monthly Review Press, 1974.

Burgess Keith, "The influence of technological change on the social attitudes and trade union policies in the British engineering industry, 1760-1860", unpublished PhD, University of Leeds, 1970.

Campbell A. B., The Lanarkshire Miners: a social history of their trade unions, 1775-1884, Edinburgh, John Donald, 1979.

Dearle Norman, Problems of Unemployment in the London Building Trades, London, J. M. Dent \& Co., 1908.

Fraser William H., "The Glasgow cotton spinners 1837", in J. Butt and J. T. Ward (eds), Scottish Themes, Edinburgh, Scottish Academic Press, 1976, p. 80-97.

Gray Robert Q., The Labour Aristocracy in Victorian Edinburgh, Oxford, Oxford University Press, 1976.

Hobsbawm Eric J., Labouring Men, London, Weidenfeld \& Nicolson, 1964.

Jones Bryn, "Destruction or redistribution of engineering skills? The case of numerical control", in S. Wood (ed.), The Degradation of Work?, London, Hutchison, 1982, p. 121-37.

Joyce Patrick, "Languages of reciprocity and conflict: a further reply to Richard Price", Social History, n 9, 1984, p. 225-231.

Knox William W., "British Apprenticeship, 1800-1914", unpublished PhD, University of Edinburgh, 1980.

-, Industrial Nation: work, culture and society in Scotland, 1800-present, Edinburgh, Edinburgh University Press, 1999. 
Levine Aaron L., "Industrial change and its affects upon Labour, 19001914", unpublished PhD, University of London, 1954.

MaChelland Keith and Reid Alistair, "Wood, iron and steel: technology, labour and trade union organisation in the shipbuilding industry, 1840-1914", in R. Harrison (ed.), Divisions of Labour: skilled workers and technological change in nineteenth century Britain, Brighton, Harvester, 1985, p. 151-184.

MaIvor Arthur J. and Kenefick William (eds), Roots of Red Clydeside, c.1910-1914: labour unrest and industrial relations in West Scotland, Edinburgh, Edinburgh University Press, 1996.

MaKinlaY Alan, "The inter-war depression and the effort bargain: shipyard riveters and the workman's foreman, 1919-1939", Scottish Economic and Social History, $\mathrm{n}^{\circ}$ 9, 1989, p. 55-70.

McShane Harry and Smith Joan, No Mean Fighter, London, Pluto Press, 1978.

Mann, Michael, The Sources of Social Power, Vol II: the rise of classes and nation states, Cambridge, Cambridge University Press, 1993.

MORRIs Robert J., "Skilled workers and the politics of the "Red Clyde", Fournal of the Scottish Labour History Society, n 18, 1984, p. 6-17.

PRICE Richard, "Structures of Subordination in Nineteenth-Century British Industry", in P. Thane et al. (eds), Power of the Past: essays for Eric Hobsbawm, Cambridge, Cambridge University Press, 1984, p. 119-142. ScotT Andrew, "The training of youth: supervision of lads from their fourteenth to their seventeenth year", Proceedings of the Philosophical Society of Glasgow, XXXVII, 1906-1907.

Steadman Walter C., "Shipbuilding", in F. Galton (ed.), Workers on their Industries, London, S. Sonnenschein, 1895.

Touraine Alain et al., Workers' Attitudes to Technical Change, Paris, Organisation for Economic Cooperation and Development, 1965.

Watson William F., Machines and Men: an autobiography of an itinerant mechanic, London, Allen and Unwin, 1935.

Yates M. L., Wages and Labour Conditions in British Engineering, London, Macdonald and Evans, 1937. 